\title{
Distinction of Gem Spinels from the Himalayan Mountain Belt
}

\author{
Anna Malsy ${ }^{\star a b}$ and Leonhard Klemm ${ }^{b}$
}

\begin{abstract}
Gem spinel deposits in Myanmar, Vietnam and Tajikistan have their formation in association with Himalayan orogenesis. Gem-quality orange, pink, red and purple spinels from deposits at Mogok (Myanmar), Luc Yen (Vietnam), and Kuh-i-Lal (Tajikistan) have been investigated by 'standard' gemological testing and laser ablation inductively coupled plasma mass spectrometry (LA-ICP-MS). Microscopic examination yielded apatite and calcite inclusions together with octahedral negative crystals to be most frequently present in Mogok spinels. The presence of dislocation systems and titanite inclusions are indicative inclusion features for spinels from Luc Yen. Trace elements such as $\mathrm{Ti}, \mathrm{Fe}, \mathrm{Ni}, \mathrm{Zn}, \mathrm{Zr}$ and $\mathrm{Sn}$ differ slightly in spinels from the sources investigated. A distinction of spinels from these deposits is therefore possible by trace element chemistry. This is especially helpful for gem spinels, which often show few inclusions or completely lack inclusion features.
\end{abstract}

Keywords: Gemstones · LA-ICP-MS · Origin determination · Spinel

\section{Introduction}

Natural magnesium-aluminum spinel $\left(\mathrm{MgAl}_{2} \mathrm{O}_{4}\right)$ as a gemstone comes in a wide palette of attractive colors. Most appreciated are red spinels, but also pink to purple and blue are amongst the favorite colors on the gemstone market. Spinel is commonly associated with ruby and occurs in metamorphic rocks as gneisses, marbles or calc-silicate felses. Most important spinel findings are in Sri Lanka, Myanmar, Afghanistan, Vietnam, Tajikistan, Madagascar, Tanzania and China. Synthetic spinel of reasonable size has been commercially produced since 1908 by the flame fusion method. Synthetic spinel is often used to imitate a variety of other gemstones due to the ease of producing different colors with the addition of various metal oxides.

${ }^{*}$ Correspondence: A. Malsyab

Tel.: +41414291717

Fax: +41414291734

E-mail: a.malsy@gubelingemlab.ch

aMineralogical Crystallography

Institute of Geological Sciences

University of Bern

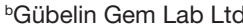

Maihofstrasse 102

$\mathrm{CH}-6006$ Lucerne
The purpose of the present study is the characterization of gem spinels from the deposits at Mogok, Myanmar, Luc Yen in Vietnam and Kuh-i-Lal mines in Tajikistan. These deposits are associated with the formation of the Himalayan Mountain Belt. Criteria for a proper assignment of gem spinel to these sources were investigated.

\section{History}

The curriculum vitae of spinel is a story full of misunderstandings. Two thousand years ago, Plinius the Elder described in his encyclopedia Naturalis Historiae (liber XXXVII) the carbunculus (from Latin meaning small piece of carbon) as the first-order red gemstone. Thus, the term carbunculi was a collective designation of red gems and further descriptions of carbunculi presumably include ruby, garnet, and probably spinel and hyacinth (yellow, brown to reddish brown variety of zircon). ${ }^{[1]}$ It was not until the twelve century that Albertus Magnus, a German bishop, mentioned a sub-division of carbunculus into balagius, granatus and rubinus and it is suggested that these indeed correspond to today's spinel, garnet and ruby, respectively. Names sounding quite similar to balagius appear in different literature, e.g. balchasch in some Arabic literature or balassi in the documentations of Marco Polo's travels. ${ }^{[2]}$ The latter texts both refer to gemstones coming from the mountains of Badakhshan province in today's northern Afghanistan, which is documented to be an early source of the finest quality ruby and spinels. Thus, it can be assumed that these more ancient names and finally 'balas ru- by', a term which today is particularly used for pale or rose-tinted spinel, derive from an ancient word for Badakshan. The name spinel possibly originates from the Latin

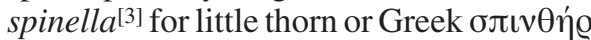
meaning spark. However, it was not until the end of the 18th century, that spinel was distinguished from ruby by chemical composition. Thus, the unreliability of its name and the lack of distinction from ruby made spinel's acceptance and recognition difficult. Even the discovery of many important historical treasures to be spinel instead of ruby, as for example the famous Black Prince's ruby in the Imperial state crown and the Timur ruby of the royal collection of the Queen of England, did not increase spinel's prestige.

Today, spinel benefits from other colored gemstones falling out of favor due to artificial treatments and market rumors. With its high diversity in color, all variants from pink to red, and its amazing transparency, spinel is gaining greater commercial importance.

\section{Materials and Methods}

For the present study, a total of $131 \mathrm{spi}$ nels from Burma, Tajikistan and Vietnam were characterized. All samples, ranging from 0.1 to $8.2 \mathrm{ct}$, were of 'gem quality' with colors of orange, red, pink or purple as the main hue.

The fluorescence behavior to standard $365 \mathrm{~nm}$ long-wave and $254 \mathrm{~nm}$ short-wave ultraviolet radiations was observed in a darkened room. Internal features were observed with a standard gemological microscope (GIA Gemolite Ultima B, Bausch \& Lomb optics) and photomicrographs were 
taken by a Nikon D80 camera. Mineral inclusions were analyzed using a Renishaw Raman 1000 spectrometer with $\mathrm{Ar}^{+}$laser at $514 \mathrm{~nm}$ excitation wavelength. Ultraviolet-visible-near infrared (UV-Vis-nIR) absorption spectra were recorded with a Perkin Elmer Lambda 19 spectrometer, in the range of $280-880 \mathrm{~nm}$. Laser ablation inductively coupled plasma mass spectrometry (LA-ICP-MS) was performed on an Perkin Elmer ELAN DRC-e single collector quadrupole mass spectrometer combined with a CETAC LSX-213 Nd:YAG laser ablation system. Helium was used as carrier gas. The LA-ICP-MS system performance was optimized to maximum intensities at $\mathrm{Th} / \mathrm{ThO}>200$ and $\mathrm{U} / \mathrm{Th} \sim 1$. Instrument settings were similar to those presented by Pettke et al. ${ }^{[4]}$ A set of four single-spot (100 $\mu \mathrm{m}$ in diameter) analyses per sample was performed on each sample at $10 \mathrm{~Hz}$ laser frequency. The calculation of concentration follows the equations given

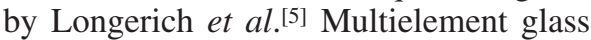
standard reference material NIST610 was used for external standardization; internal standardization was done by normalization to $100 \%$ cations of pure stoichiometric spinel.

\section{Geology and Mining}

Spinel deposits from central to Southeast Asia are located within the Himalayan mountain belt which formed during the Tertiary continental collision between the Indian subcontinent and Eurasia. ${ }^{[6]}$ Spinel and/or ruby occur in platform carbonate series that underwent high-temperature amphibolite to lower granulite grade regional metamorphism. ${ }^{[7]}$ These marbles consist of calcite, dolomite, phlogopite, margarite, amphibole, chlorite, fortsterite, and titanite \pm graphite \pm garnet \pm pyrite . The marble units are generally associated with intercalations of garnet-biotite-sillimanite- or biotite-kyanite-bearing gneisses, schists, quarztites and amphibolites. Dikes of granite and/or pegmatite intruded these metamorphosed rocks. ${ }^{[8]}$

\section{Myanmar - Mogok}

Burma, nowadays Myanmar, is not only famous for its finest rubies of so-called 'pigeon blood' color, but also for intensely red-colored spinels. The deposits around Mogok have been exploited for rubies since the sixth century, ${ }^{[9]}$ as documented by ancient legends. Mogok rubies are still today some of the highest priced gemstones of the world. The 'Mogok Stone Tract' is located in the Mandalay division and comprises several localities surrounding Mogok. Significant amounts of spinel are found at virtually all of the corundum mines, ${ }^{[10]}$ from primary as well as secondary deposits.

Geological mapping of the 'Mogok Stone Tract' was doneby Iyerin the 1950s. ${ }^{[11]}$ More recent investigations are lacking, as access to the mining area is limited to foreigners due to political changes in 1960s. The gem deposits occur in the Mogok Metamorphic Belt (MMB). This belt is marked by high-temperature ductile deformation from Oligocene stretching to post-Miocene brittle dextral faults resulting from the oblique Indio-Asian collision. ${ }^{[6,12]}$ Ruby and spinel are disseminated within marbles in a mineral association with phlogopite, muscovite, scapolite, margarite, titanite, pyrite, and graphite. ${ }^{[8,13]}$ The marble units consist of discontinuous horizons up to $300 \mathrm{~m}$ in thickness, interbedded with calcschists or sillimanite-bearing gneisses. ${ }^{[6]}$ They are generally coarsely crystallized and typically pure white in color. ${ }^{[14]}$ Dikes of granite, minor syenite, and associated pegmatites intruded into the metamorphic rocks. The influence of the latter intrusives on the formation of gem ruby was discussed by several authors. ${ }^{[11,14,15]}$ Most recent investigations ${ }^{[6]}$ indicate that ruby formation was probably strictly associated with high-temperature metamorphism.

The tropical climate with high rainfall and strong weathering leads to residual accumulation of chemically and mechanically resistant minerals and ultimately to the formation of secondary gemstone deposits. Gem-bearing beds are characteristically brown and yellow and contain clays, iron oxides and sometimes sandy material, locally known as 'byon'.[14] With today's political situation in Myanmar there is unfortunately no firsthand information on mining activities and production. Previous information on mining production gives only distinctive details on ruby and sapphire. However, Mogok spinels are available on the gemstone market in a variety of color hue, saturation and tone, from intense red to orange and purple, as well as pink from very light tones to intense pink.

\section{Vietnam - Luc Yen}

Luc Yen is located in the northern part of Vietnam in the Yen Bai province. The city of Luc Yen is the center of gemstone mining and trading in the area. The first discovery of ruby in northern Vietnam was in 1983. Serious mining of the occurrences did not start before 1988, [16] but spinel findings are reported from that time.

The deposits from Luc Yen are located in weakly deformed marble units hosted by metamorphic belts associated with the southern Red River Shear zone, which was active during the Cenozoic. ${ }^{[17]}$ Geothermo- barometric studies revealed a peak metamorphism at amphibolite-facies conditions. ${ }^{[18]}$ Amphibolite bodies are alternated with calcitic and/or dolomitic marble. ${ }^{[8]}$ Surrounding gneisses or schists show assemblages of biotite-garnet-sillimanite \pm scapolite \pm kyanite \pm amphibole \pm clinopyroxene. ${ }^{[6]}$ For the gem-bearing marbles, literature data agree on two different types or assemblages. Garnier et al. ${ }^{[13]}$ indicate a marble-parageneses of spinel + ruby \pm chlorite \pm amphibole \pm olivine \pm humite \pm graphite \pm pyrite. A second, spinel-free paragenesis, is given as ruby + phlogopite + feldspar \pm muscovite \pm paragonite \pm amphibole \pm graphite \pm tourmaline \pm apatite \pm titanite \pm pyrite \pm pyrrhotite. These authors further state a destabilization of spinel in contact with calcite during retrograde metamorphism as the principle reaction for ruby formation. A more distinct separation into spinel- and ruby-bearing marbles is stated by other authors. ${ }^{[19,20]}$

Placer deposits are the main source for gem spinel. The secondary deposits consist of gravel fillings in karst pockets or are located in alluvial fans of the Luc Yen valleys. Open-pit mining is the dominant method used and associated gem minerals are pink to red corundum, yellow and green tourmalines and garnets. ${ }^{[16]}$ Vietnamese spinels are known for both their bright and pastel-pink color. There is, however, a broad variety of colors from orange to pinkish-red and purple, but also pale blue spinel is available. Pure red spinels are rather rare from Vietnam.

\section{Tajikistan - Kuh-i-Lal}

The Kuh-i-Lal mines are situated on the Tajik side of the Badakhshan region, which comprises parts of today's northeastern Afghanistan. The historic mine is amongst the oldest of the world and source of the so-called 'Balas Rubies', which are actually pale rose-tinted spinel.

The Kuh-i-Lal deposits are situated within southwest Pamir Mountains, which are designated by extensive development of ultra-magnesian metamorphic assemblages ${ }^{[21]}$ in the Goran series. The Goran series consists of metasedimentary rocks, dominantly biotite gneiss and migmatite, marble and calc-silicate rocks, and subordinate quartzite and amphibolites. ${ }^{[22]}$ The ultra-magnesian rocks include 'whiteschist' (talc-kyanite rocks), enstatite- and forsterite-rich skarns, and kornerupinebearing skarns and schists.

\section{Results}

Results for microscopic and spectroscopic features, as well as chemical com- 
Table 1. Summary of gemological properties (color, refractive index, specific gravity, fluorescence, microscopic features)

\begin{tabular}{|c|c|c|c|}
\hline Property & Mogok, Myanmar & Luc Yen, Vietnam & Kuh-i-Lal, Tajikistan \\
\hline Color & $\begin{array}{l}\text { Red, orangey red, pinkish red, pink } \\
\text { (light or medium in tone), orangey } \\
\text { pink, purple, orange }\end{array}$ & $\begin{array}{l}\text { Red, orangey red, pink (light or } \\
\text { medium in tone), orangey pink, } \\
\text { reddish pink, purple, orange }\end{array}$ & Pink (light in tone) 'rose' \\
\hline Refractive index (RI) & $\begin{array}{l}n=1.715 \text { (pink, light in tone) to } \\
n=1.719 \text { (pink) }\end{array}$ & $\begin{array}{l}n=1.714 \text { (pink, light in tone) to } \\
n=1.719 \text { (pink) }\end{array}$ & $\mathrm{n}=1.712$ to 1.713 \\
\hline Specific gravity (SG) & $3.59-3.61$ & $3.59-3.61$ & $3.58-3.59$ \\
\hline $\begin{array}{l}\text { UV fluorescence } \\
\text { Long-wave } \\
\text { Short-wave }\end{array}$ & $\begin{array}{l}\text { inert to strong; red } \\
\text { inert to weak red }\end{array}$ & $\begin{array}{l}\text { inert to strong; red } \\
\text { inert to very weak; red }\end{array}$ & $\begin{array}{l}\text { medium to strong; red } \\
\text { weak; orange, yellow (at surface) }\end{array}$ \\
\hline Internal features & $\begin{array}{l}\text { apatite ('belly button') } \\
\text { calcite } \\
\text { dolomite } \\
\text { anhydrite } \\
\text { magnesite } \\
\text { graphite } \\
\text { potassium feldspar } \\
\text { chondrodite } \\
\text { Partially healed fissures } \\
\text { Octahedral negative crystal : filled } \\
\text { by calcite or dolomite; isolated with } \\
\text { cross cutting needle-like inclusion; } \\
\text { perching on a partially healed fissure; } \\
\text { with equatorial tension disc; circled } \\
\text { by accretion clouds; lined-up in rows }\end{array}$ & $\begin{array}{l}\text { apatite } \\
\text { calcite } \\
\text { dolomite } \\
\text { zircon (tension crack; cluster) } \\
\text { magnesite } \\
\text { graphite } \\
\text { potassium feldspar } \\
\text { titanite ("sphene") } \\
\text { Partially healed fissures composed of } \\
\text { arranged fluid inclusions } \\
\text { Monodirectional, parallel blades of } \\
\text { short needles (högbomite?) } \\
\text { Primary two-phase inclusions } \\
\text { Dislocation channels: bands or as } \\
\text { stellate networks; outgoing from fluid } \\
\text { inclusions; with cut-off by growth } \\
\text { steps }\end{array}$ & $\begin{array}{l}\text { zircon } \\
\text { Poorly healed fissures with coarse } \\
\text { texture, cavities partially filled by } \\
\text { double refractive substance and } \\
\text { "tails" } \\
\text { Planes of negative crystals } \\
\text { Octahedral negative crystal : isolated } \\
\text { with cross cutting needle-like } \\
\text { inclusion; with attached black platelet } \\
\text { Crystal inclusion associated with } \\
\text { particulate trails = "comet-tails" }\end{array}$ \\
\hline
\end{tabular}

position by LA-ICP-MS are given in the following section. A summary of gemological features is given in Table 1 .

\section{Microscopic Features}

Mineral inclusions and octahedral negative crystals are the most prominent features in Mogok spinels. The appearance of slightly rounded, more or less spherical apatite crystals with a black graphite or ilmenite platelet attached on a basal pinacoid (Fig. 1) is quite specific and often characterized as a highly diagnostic feature for spinel from Mogok. ${ }^{[23]}$ However, these so-called 'belly-button' inclusions were observed in some of the spinels only,

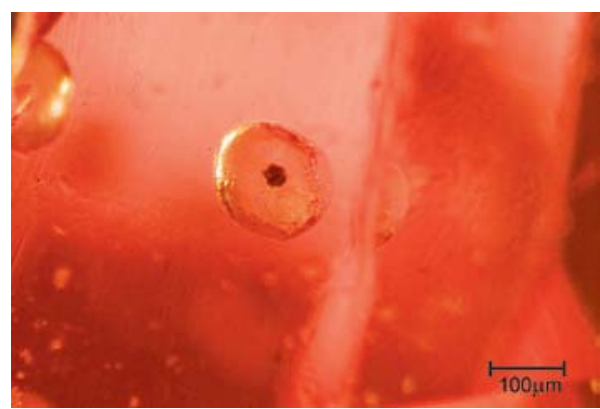

Fig. 1. Rounded apatite inclusion with attached black graphite platelet. This inclusion feature is also described as 'belly button' and is considered a diagnostic inclusion in spinel from Mogok, Myanmar. more specifically in samples from the former Dr. Gübelin collection. These samples further show rows of lined-up negative crystals, as well as negative crystals encircled by accretion clouds. All other spinels are characterized by calcite of variable appearance and octahedral negative crystals as dominant inclusion features. Octahedral negative crystals may be transparent or of more turbid white aspect and are partly filled by calcite and/or dolomite substance. Occasionally they are accompanied by an equatorial stress crack, partially healed fissure or accretion clouds of minute light scattering particles. Some octahedral negative crystals are also penetrated by a needle-like crystal. Isolated graphite platelets are observed and less frequently mineral inclusions of anhydrite, magnesite, feldspar, and chondrodite.

The most striking inclusion feature of spinels from Luc Yen is the presence of dislocation systems. These appear as intersecting bands of iridescent parallel oriented channels (Fig. 2) or build three-dimensional stellate networks. Single bands with distinct cut-offs can be observed and are most probably generated by bisecting growth steps. In a few samples, mono-directional parallel blades of needles (possibly högbomite) can be observed. A wide variety of mineral inclusions were identified by Raman spectroscopy; these are zircon, apatite, calcite,

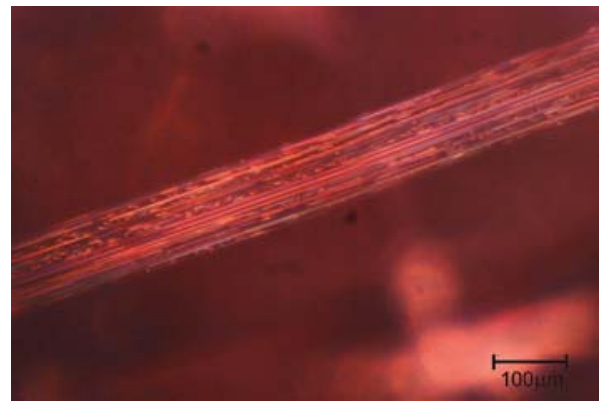

Fig. 2. Band of an oriented dislocation system within spinel from Luc Yen, Vietnam.

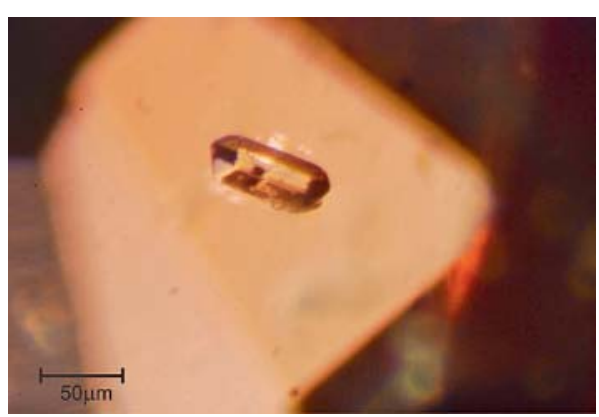

Fig. 3. Well-developed zircon inclusion with tension crack within a spinel from Luc Yen, Vietnam.

dolomite, titanite, graphite, and potassium feldspar ( $75 \%$ orthoclase). Zircon crystals (Fig. 3) occur slightly rounded 


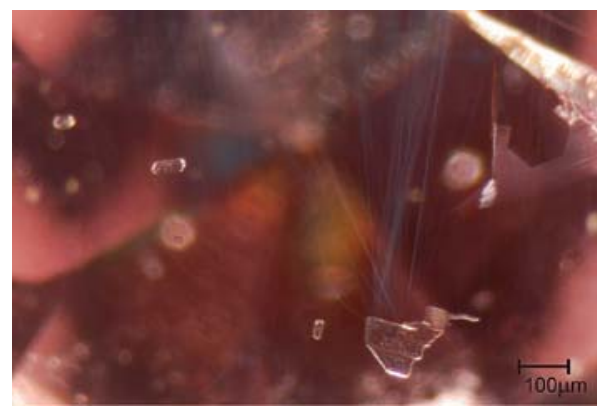

Fig. 4. Inclusion scene in a spinel from Tajikistan with small prismatic zircon crystals. An unknown colorless crystal inclusion is accompanied by divergent particulate trails forming so-called 'comet-tails'.

in clusters or as well-developed prisms accompanied by tension cracks. Partially healed fissures with fluid inclusions arranged in a pattern are rarely seen.

Spinels investigated from Tajikistan have few inclusions. Negative octahedra were observed. These can be associated with a needle-like inclusion at the octahedron's tip or a black graphite platelet. Planes of elongated negative crystals are common. Euhedral zircon crystals and tabular to prismatic colorless mineral inclusions (most probably phlogopite) were observed. In association with mineral in- clusions, diverging stringers of delicate light-scattering particles (Fig. 4) were seen in some samples. Poorly developed healed fissures with coarse constituents are sometimes present.

\section{Chemical Composition}

In Table 2, selected LA-ICP-MS data are summarized and given as ranges, mean values and standard deviations. The elements $\mathrm{V}, \mathrm{Cr}, \mathrm{Fe}$ and $\mathrm{Zn}$ were commonly present in highest concentrations whereas $\mathrm{Ti}, \mathrm{Ga}$, and $\mathrm{Mn}$ contents were generally low. Traces of $\mathrm{Li}, \mathrm{Be}, \mathrm{Co}, \mathrm{Ni}, \mathrm{Cu}, \mathrm{Zr}$ and $\mathrm{Sn}$ were detected, other investigated elements were below the detection limits (Table 1). Highest $\mathrm{Zn}$ concentrations have been observed for Mogok spinels. Spinels from Mogok are further characterized by the highest Ti, V, Cr, Ga and Sn contents. Investigated samples from Luc Yen stand out by having the highest Fe content (up to 2.2 wt $\left.\% \mathrm{Fe}_{2} \mathrm{O}_{3}\right)$, as well as low $\mathrm{Ti}(<0.04 \mathrm{wt} \%$ $\left.\mathrm{TiO}_{2}\right)$ and $\mathrm{Sn}(<0.5 \mu \mathrm{g} / \mathrm{g})$ concentrations. Samples from Tajikistan show intermediate values for $\mathrm{Ti}, \mathrm{V}, \mathrm{Cr}, \mathrm{Fe}, \mathrm{Zn}$, and $\mathrm{Ga}$. Nickel and $\mathrm{Zr}$ are typically close or below the detection limit in Tajik spinels. The homogeneity of trace elements within all individual samples is generally quite high, with mean variations of $<7 \%$ for $\mathrm{V}, \mathrm{Zn}, \mathrm{Ga}$, and mean variation of $<10 \%$ for $\mathrm{Li}, \mathrm{Ti}, \mathrm{Cr}$, $\mathrm{Mn}$ and $\mathrm{Fe}$. The variation of trace element concentrations is strongest for Mogok spinels.

The color of Mogok spinel strongly depends on $\mathrm{Cr}$, with minor influence of $\mathrm{Fe}$ and $\mathrm{V}$ concentrations (Fig. 5a). The $\mathrm{Cr}$ content of the investigated spinels shows variations from $0.001 \mathrm{wt} \%$ in light orange up to 2.6 wt $\% \mathrm{Cr}_{2} \mathrm{O}_{3}$ in red samples. The Fe content ranges from 0.002 to $1.2 \mathrm{wt} \% \mathrm{Fe}_{2} \mathrm{O}_{3}$. Red to pinkish red samples generally contain more $\mathrm{Cr}$ than $\mathrm{Fe}$ whereas $\mathrm{Fe}$ significantly exceeds $\mathrm{Cr}$ concentrations in purple spinels. Lower variation in the concentration of chromophores $\mathrm{Cr}$ and $\mathrm{Fe}$ is observed for spinels from Luc Yen, Vietnam and Kuhi-Lal, Tajikistan (Fig. 5b). Samples investigated from Vietnam showed $\mathrm{Cr}$ contents from $0.05 \mathrm{wt} \% \mathrm{Cr}_{2} \mathrm{O}_{3}$ in light pink to 1.3 wt $\% \mathrm{Cr}_{2} \mathrm{O}_{3}$ in pinkish red samples. The $\mathrm{Fe}$ content ranges from 0.18 to $2.2 \mathrm{wt} \% \mathrm{Fe}_{2} \mathrm{O}_{3}$ and equals or exceeds the $\mathrm{Cr}$ concentration with the exception of one sample. Orange spinels investigated from Myanmar and Vietnam typically have higher $\mathrm{V}$ than $\mathrm{Cr}$ contents. As expected from their quite uniform light pink color, spinels from Tajikistan are most homogeneous regarding chromophore contents $\left(\mathrm{Cr}_{2} \mathrm{O}_{3}: 0.04-0.13\right.$ $\mathrm{wt} \%$ and $\left.\mathrm{Fe}_{2} \mathrm{O}_{3}: 0.13-0.52 \mathrm{wt} \%\right)$.

\section{UV-Vis Spectroscopy}

According to the dominant colorcausing trace elements, different types of

Table 2. Chemical composition by LA-ICP-MS given as ranges, mean values (mean) and standard deviation (sdev)

\begin{tabular}{|c|c|c|c|c|c|c|}
\hline \multirow[b]{2}{*}{ wt\%a } & \multicolumn{2}{|c|}{ Mogok, Myanmar } & \multicolumn{2}{|c|}{ Luc Yen, Vietnam } & \multicolumn{2}{|c|}{ Kuh-i-Lal, Tajikistan } \\
\hline & range & mean + sdev & range & range + sdev & range & mean + sdev \\
\hline $\mathrm{V}_{2} \mathrm{O}_{3}$ & 0.004-1.019 & $0.261 \pm 0.202$ & $0.004-0.323$ & $0.101 \pm 0.099$ & $0.028-0.068$ & $0.048 \pm 0.010$ \\
\hline $\mathrm{Cr}_{2} \mathrm{O}_{3}$ & $0.001-2.614$ & $0.497 \pm 0.550$ & $0.053-1.271$ & $0.291 \pm 0.251$ & $0.036-0.127$ & $0.059 \pm 0.016$ \\
\hline $\mathrm{Fe}_{2} \mathrm{O}_{3}$ & $0.002-1.217$ & $0.226 \pm 0.235$ & $0.182-2.228$ & $0.722 \pm 0.463$ & $0.134-0.523$ & $0.330 \pm 0.075$ \\
\hline $\mathrm{ZnO}$ & $0.045-2.757$ & $0.461 \pm 0.546$ & $0.014-0.889$ & $0.222 \pm 0.243$ & $0.045-0.144$ & $0.108 \pm 0.022$ \\
\hline \multicolumn{7}{|l|}{$\mu \mathrm{g} / \mathrm{g}^{\mathrm{b}}$} \\
\hline $\mathrm{Li}$ & $0.14-343$ & $43 \pm 63$ & $2.3-814$ & $115 \pm 211$ & $7.1-21$ & $15 \pm 2.3$ \\
\hline $\mathrm{Be}$ & $<^{\circ} 0.14-141$ & $17 \pm 24$ & $2.4-34$ & $10 \pm 7.0$ & $5.9-13$ & $9.3 \pm 1.4$ \\
\hline $\mathrm{Ti}$ & $4.0-1566$ & $370 \pm 355$ & $0.78-194$ & $60 \pm 33$ & $47-114$ & $84 \pm 12$ \\
\hline $\mathrm{Mn}$ & $2.6-812$ & $51 \pm 137$ & $3.1-179$ & $56 \pm 42$ & $67-120$ & $92 \pm 11$ \\
\hline Co & $<0.024-14$ & $2.1 \pm 2.5$ & $0.28-15$ & $4.5 \pm 3.7$ & $0.40-1.5$ & $0.85 \pm 0.20$ \\
\hline $\mathrm{Ni}$ & $<0.49-78$ & $35 \pm 41$ & $<0.43-245$ & $37 \pm 51$ & $<0.33-2.0$ & $0.58 \pm 0.39$ \\
\hline $\mathrm{Cu}$ & $<0.18-1.2$ & $0.40 \pm 0.19$ & $0.13-5.0$ & $0.35 \pm 0.43$ & $<0.15-1.4$ & $0.30 \pm 0.22$ \\
\hline $\mathrm{Ga}$ & $1.3-401$ & $137 \pm 79$ & $21-355$ & $137 \pm 79$ & $136-275$ & $180 \pm 129$ \\
\hline $\mathrm{Zr}$ & $<0.024-0.43$ & $0.041 \pm 0.039$ & $<0.016-0.086$ & $0.025 \pm 0.018$ & $<0.013-0.047$ & $0.020 \pm 0.015$ \\
\hline Sn & $<0.14-26$ & $1.1 \pm 3.2$ & $<0.11-0.49$ & $0.16 \pm 0.073$ & $<0.084-0.71$ & $0.31 \pm 0.028$ \\
\hline
\end{tabular}



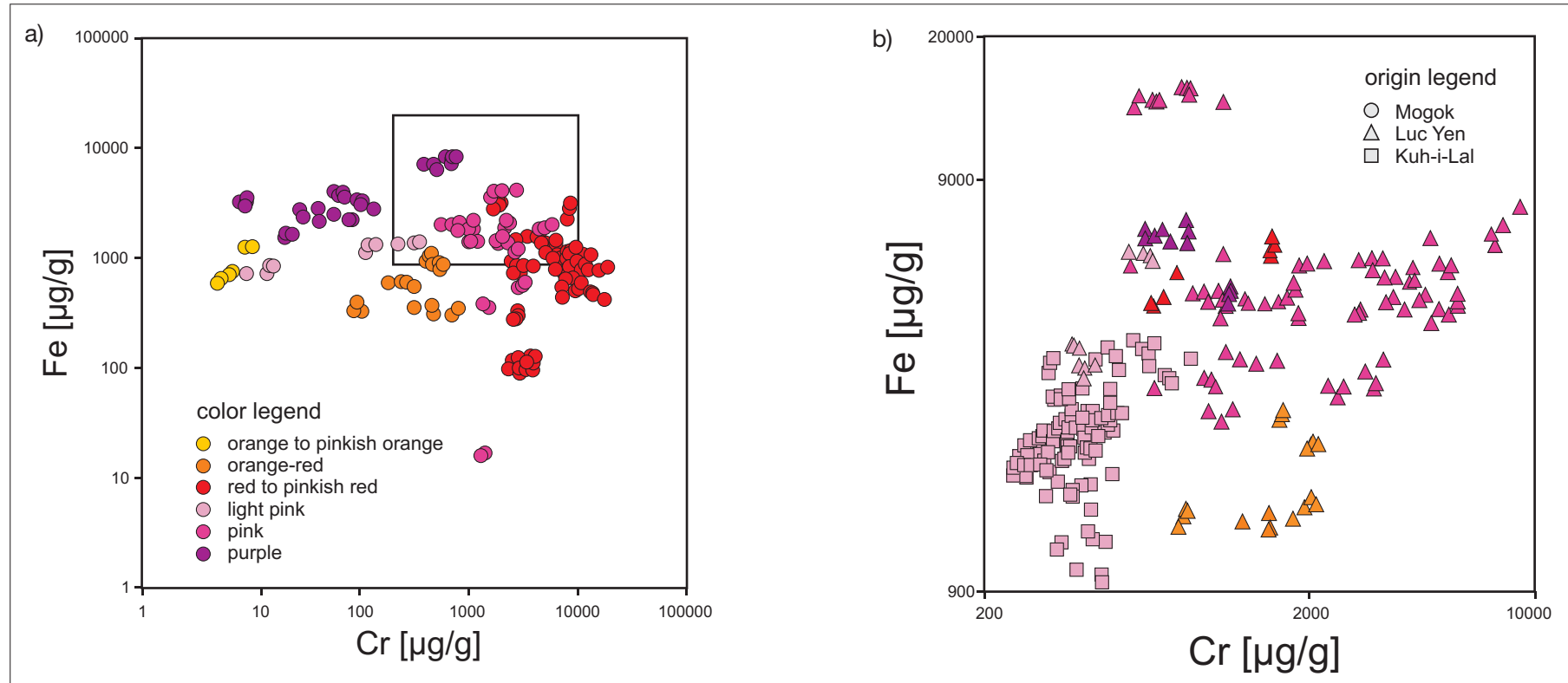

Fig. 5. Diagram showing Cr vs. Fe contents: a) Investigated spinels from Mogok show a wide range of $\mathrm{Cr}$ contents from 0.001 to $2.6 \mathrm{wt} \% \mathrm{Cr}_{2} \mathrm{O}_{3}(5$ to $18^{\prime} 000 \mu \mathrm{g} / \mathrm{g}$ ), causing light pink to pink and red colors. The Fe content ranges from 0.002 to $1.2 \mathrm{wt} \% \mathrm{Fe}_{2} \mathrm{O}_{3}\left(15\right.$ to $\left.8^{\prime} 600 \mu \mathrm{g} / \mathrm{g}\right)$ and is responsible for purple colored spinels when significantly exceeding the $\mathrm{Cr}$ concentrations. b) $\mathrm{Cr}$ and $\mathrm{Fe}$ of spinels from Luc Yen have lower variation from 0.05 to $1.3 \mathrm{wt} \% \mathrm{Cr}_{2} \mathrm{O}_{3}\left(346\right.$ to $8^{\prime} 700 \mathrm{\mu g} / \mathrm{g}$ ) and higher Fe contents (up to $2.2 \mathrm{wt} \% \mathrm{Fe}_{2} \mathrm{O}_{3}$ ) compared to samples from Mogok. Spinels from Kuh-i-Lal are quite homogeneous within $\mathrm{Cr}$ and $\mathrm{Fe}$, as expected from their homogeneous color.

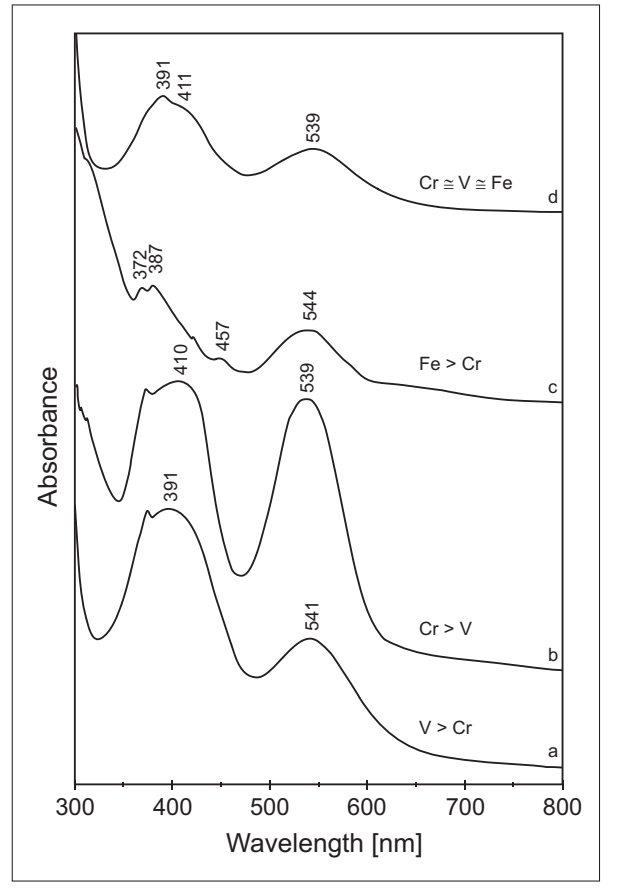

Fig. 6. Absorption spectra of spinels of type: a) $\mathrm{V}>\mathrm{Cr}$ (orange-red spinel, Mogok); b) $\mathrm{Cr}>\mathrm{V}$ (red spinel, Mogok); c) Fe > Cr (purple spinel, Vietnam); d) $\mathrm{Cr} \cong \mathrm{V} \cong \mathrm{Fe}$. Absorption spectra b) and c) represent predominant $\mathrm{Cr}^{3+}$ and $\mathrm{Fe}^{2+}$ spectra, respectively. Absorption bands with maxima at 410, 411 and $539 \mathrm{~nm}$ are attributed to $\mathrm{Cr}^{3+}$ on octahedral sites and maxima at 372 and 457 to $\mathrm{Fe}^{2+}$. In spectrum a) the observed maximum at $391 \mathrm{~nm}\left(\mathrm{Cr}^{3+}\right.$ at $\left.410 \mathrm{~nm}\right)$ is caused by $\mathrm{V}^{3+}{ }^{[24]}$ on octahedral sites whereas the absorption band at $539 \mathrm{~nm}$ represents superposition of $\mathrm{V}^{3+}+\mathrm{Cr}^{3+}$ absorption. Spectrum d) shows superimposed $\mathrm{Cr}^{3+}+\mathrm{V}^{3+} \pm$ $\mathrm{Fe}^{2+}$ absorption features.

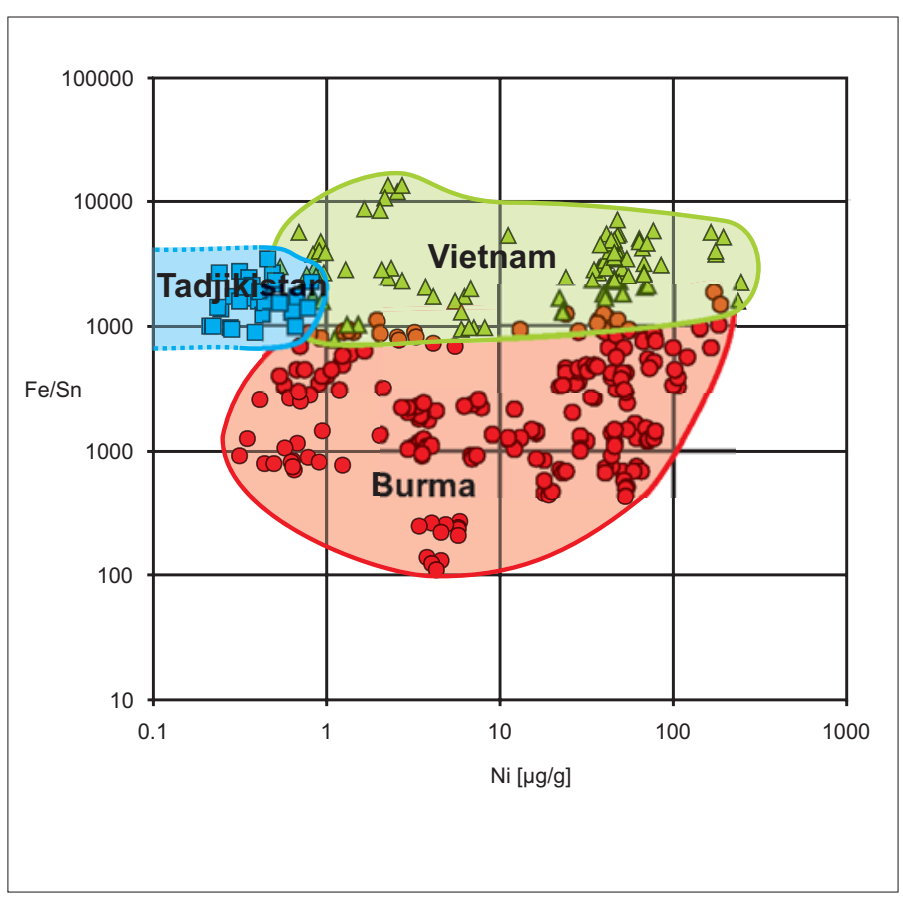

Fig. 7. Plot Ni $[\mu \mathrm{g} / \mathrm{g}]$ versus $\mathrm{Fe} / \mathrm{Sn}$ ratio by LA-ICP-MS data. Spinels from Mogok, Myanmar and Luc Yen, Vietnam show only slightly overlapping data in their $\mathrm{Fe} /$ Sn ratio. A proper distinction of spinels from these origins can be achieved by considering additional trace elements. Spinel from Tajikistan is characterized by $\mathrm{Ni}$ contents close to or below the detection limit $(<0.2 \mu \mathrm{g} / \mathrm{g})$.

spectra could be recorded (Fig. 6). Literature data ${ }^{[24]}$ indicate a grouping into predominantly $\mathrm{Cr}$ and V-bearing, Fe-bearing, $\mathrm{Fe}$ and $\mathrm{Co}$-bearing and $\mathrm{Fe}$ and $\mathrm{Mn}$ bearing spinels. Results of the present study comprise the first and second type only. Based on literature data, ${ }^{[24]}$ and the general principles of ligand field theory, the following assignment of absorption bands can be done. Absorption maxima at about 410 and $540 \mathrm{~nm}$ are attributed to $\mathrm{Cr}^{3+}$ (Fig. 6b) and maxima at 391 and 558 $\mathrm{nm}$ to $\mathrm{V}^{3+}$ at octahedral sites. As natural spinels usually contain both trace elements, a superposition of the individual absorption spectra is observed. Purple spinels with dominant amount of $\mathrm{Fe}$ showed absorption maxima at 372, 387, 457 and $544 \mathrm{~nm}$ (Fig. 6c). Investigations of Mössbauer spectroscopy ${ }^{[25-27]}$ indicate $\mathrm{Fe}^{2+}$ at tetrahedral sites to be responsible for these maxima, except the broad band at $544 \mathrm{~nm}$, which results from superimposition of $\mathrm{Cr}$ and $\mathrm{Fe}$. 


\section{Discussion}

Chemical analysis showed gem-quality spinels to be almost pure $\mathrm{MgAl}_{2} \mathrm{O}_{4}$ endmembers with $\mathrm{Zn}, \mathrm{Cr}$ and $\mathrm{Fe}$ not exceeding 0.05 atoms per formula unit (apfu). Due to a limited presence of trace elements and similar formation condition, spinels display few origin-specific characteristics in their trace element pattern. Spinels from Luc Yen deposit in Vietnam differ mainly by high $\mathrm{Fe}$ and low Sn concentrations from spinels of the Mogok deposit (Fig. 7). By additionally considering $\mathrm{V}, \mathrm{Ti}$ and $\mathrm{Zr}$, a proper distinction of these two deposits can be achieved. The strong variation of trace elements within Mogok spinels obviously results from the widespread mining pits over a complex geological region. The dominant feature in spinels from Mogok are mineral inclusions (mostly apatite and calcite) together with octahedral negative crystals. In contrast to spinels from Vietnam and Tajikistan, no zircon inclusions were observed. However, the Mogok spinels had the highest zirconium concentrations. The presence of dislocation systems and titanite inclusions are strongly indicative features for Vietnamese spinels. The rose-tinted spinels from Kuh-i-Lal mines in Tajikistan show typically only few inclusions and generally have intermediate to low concentrations of trace elements compared to Mogok and Luc Yen spinels. A yellow surface fluorescence under shortwave UV was observed for samples from Tajikistan only. This specific fluorescence behavior was previously observed for purplish-pink Tajik spinels. [28]

In summary, it was found that despite of the quite similar geological setting, trace elements such as $\mathrm{Ti}, \mathrm{Fe}, \mathrm{Ni}, \mathrm{Zn}, \mathrm{Zr}$ and Sn differ for the deposits investigated. A careful examination of the trace element pattern therefore allows a differentiation of spinels from Mogok, Luc Yen and Kuhi-Lal by chemistry only. This is a prerequisite for origin determination of spinels, which occasionally challenge gemologists by their absence of inclusions.

\section{Acknowledgements}

Hans-Georg Wild (Paul Wild OHG, Kirschweiler, Germany), Michael Hügi (Schweizerische Gemmologische Gesellschaft SGG, Switzerland), Dr. Michael Krzemnicki (Swiss Gemmological Institute SSEF, Basel, Switzerland), and Dr. Dietmar Schwarz (Gübelin Gem Lab GGL, Lucerne, Switzerland) are thanked for supplying us with additional samples. Mingling Zheng and Beryl Huber kindly performed UV-Vis spectra and refractive indices, respectively. Prof. Thomas Armbruster (Institute of Geological Sciences, University of Bern, Switzerland) kindly helped us with professional advice and discussions. Eva Wadoski is thanked for English corrections. Dr. Dietmar Schwarz is thanked for the review of the present article.

Received: June 23, 2010

[1] R. Gerber, 'Apokalyptische Steine von Plinius und heute', Books on demand GmbH, 2002.

[2] C. Keferstein,. 'Mineralogia Polyglotta', $w w w$. gutenberg.net, 2005.

[3] J. W. Anthony, R. A. Bideaux, M. C. Nichols, in 'Handbook of Mineralogy Vol. 3', Tuscon, Arizona, Mineral Data Publishing, 1997, 521.

[4] T. Pettke, W. E. Halter, J. D. Webster, M. Aigner-Torres, C. A. Heinrich, Lithos 2004, 333.

[5] P. H. Longerich, E. S. Jackson, D. Günther, J. Anal. At. Spectrom. 1996, 899

[6] V. Garnier, H. Maluski, G. Giuliani, D. Ohnenstetter, D. Schwarz, Can. J. Earth. Sci. 2006, 509.

[7] C. A. Hauzenberger, T. Häger, L. P. Baumgartner, W. Hofmeister, in 'International workshop on material characterization by solid-state spectroscopy: gems and minerals of Vietnam', Hanoi, 2001.

[8] G. Giuliani, D. Ohnenstetter, V. Garnier, A. E. Fallick, M. Rakootondrazafy, D. Schwarz, in 'Geology of gem deposits', Canada: Mineralogical Association of Canada, 2007.

[9] H. L. Chhibber, in 'The mineral resources of Burma', McMillan \& Co, London, 1934.

[10] R. Kane, C. Kammerling, Gems Gemol. 1992 $28,152$.

[11] L. A. Iyer, Memy India. Geol. Surve 1953, 82.

[12] G. Bertrand, C. Rangin, Geophysic. Res. Lett. 2003, 915.

[13] V. Garnier, G. Guiliani, D. Ohnenstetter, A. E. Fallick, J. Dubessy, D. Banks, Ore Geol. Rev. 2008, 169.

[14] C. Keller, Gems Gemol. 1983, 19, 209.

[15] L. N. Rossovskiy, S. I. Konovalekno, S. A. Ananjev,. Geol. Rudnyh Mestorozhd. 1982, 57 (in Russian).
[16] R. E. Kane, S. F. McClure, R. C. Kammerling, N. D. Khoa, C. Mora, S. Repetto, (1991) Gems Gemol. 1991, 27, 136.

[17] U. Schärer, P. Tapponnier, R. Lacassin, R Leloup, D. Zhong, S. Ji, Earth and Planetary Science Letters 1990, 65.

[18] P. H. Leloup, J. R. Kienast, Earth Planet. Sci. Lett. 1993, 213.

[19] C. Sutthirat, S. Lapngamchana, V. PisuthaArnond, N. N. Khoi, in 'International symposia on geoscience Resources and Environments of Asian Terranes', Bangkok, 2008.

[20] D. P. Tien, W. Hofmeister, V. X. Quang, Appl. Mineral. 2000, 281.

[21] W. Schreyer, K. Abraham, K., Contrib. Mineral. Petrol. 1976, 111.

[22] M. S. Hubbard, E.S. Grew, K.V. Hodges, M. G. Yates, N. N. Pertsev, Tectonophysics 1999, 325.

[23] E. J. Gübelin, J. I. Koivula, 'Photoatlas of Inclusions in Gemstones Volume 2', Opinio Publishers, Basel, 2005

[24] K. Schmetzer, C. Haxel, G. Amthauer, Neues Jahrb. Mineral., Abh. 1989, 160.

[25] K. Ono, L. Chandler, A. Ito, Phys. Lett. 1967, 273.

[26] B. Dickson, G. Smith, Can. Mineral. 1976, 206.

[27] V. V. Bukanov, A. N. Platonov, M. N. Taran, Vses. Mineral. Osh. 1977, 565. (in Russian).

[28] N. Sturman, Gems Gemol. 2009, 57. 